\title{
KAJIAN SEMIOTIKA: STYLE YAMI KAWAII DAN KESEHATAN MENTAL
}

\author{
1Mestika Nawang Sukma, ${ }^{2}$ Acep Iwan Saidi, ${ }^{3}$ Vyana Lohjiwa \\ ${ }^{1}$ Mahasiswa Pascasarjana Desain ITB, ${ }^{2}$ Dosen Pascasarjana Desain ITB, ${ }^{3}$ Dosen STP NHI Bandung \\ 1,2Institut Teknologi Bandung, ${ }^{3}$ STP NHI Bandung \\ 1mestikanawang@gmail.com, 2acepiwansaidi@gmail.com, 32vyl@stp-bandung.ac.id
}

\begin{abstract}
I speak through my clothes, at this time the function of today's fashion is not only as a cover of the body for the sake of modesty, but as a way of communicating. Fashion communication can be conveyed through clothing, costumes, and make-up which associated with the latest issues, such as mental health. WHO revealed that 450 million people in the world had suffer from mental disorders, and more than 150 million people have experience depression. Yami Kawaii is a fashion style that represents a depressive style of clothing with a cute touch. The Yami Kawaii fashion users trying to communicate to others about how they suffer from psychological or mental disorders by combining visual elements such as injection, bandages, pills, plasters and tools that are often used for suicide, such as weapons and ropes combined into a pastel dress with a heart motif, and some writing in a beautiful font, as part of kawaii. This research uses Roland Barthes' semiotic theory approach in shaping the meaning of denotation, connotation, and myth. This study aims to examine the relationship between visual elements in the Yami Kawaii style in forming meanings related to mental health. This study uses text analysis using 5 styles of Yami Kawaii looks from head-to-toe style and then examined using elements of fashion with six (6) elements of fashion, including: (1) Silhouettes, (2) Lines, (3) Details, (4) Fabric, (5) Motif, (6) Colors in clothing (apparel) and fashion accessories. The results of this study indicate that there are denotative, connotative, and mythical meanings of the Yami Kawaii Style which are related to mental health issues.
\end{abstract}

Keywords: Yami Kawaii, Semiotic, Fashion, Mental Health

\section{PENDAHULUAN}

"I speak through my clothes", Fungsi fashion pada masa kini tidak hanya sebagai pelindung atau penutup tubuh demi kesopanan (modesty), tetapi sebagai suatu cara berkomunikasi, hal ini diungkapkan pula oleh Umberto Eco (1973). Diungkapkan lebih lanjut oleh Barnard (1995), pakaian dipandang memiliki suatu fungsi komunikatif. Busana, pakaian, kostum dan dandanan adalah bentuk komunikasi artifaktual (artifactual communication). Pakaian yang kita kenakan mengungkapkan pernyataan, pakaian yang mereka pakai serta kombinasinya memiliki atau dapat memberi makna tertentu (Davis, 1993). Saat ini, fashion digunakan untuk mengangkat isu terkini yang relevan dengan perkembangan zaman salah satunya adalah isu tentang mental health. Data WHO (2010) menunjukkan sebanyak 450 juta orang di dunia menderita gangguan jiwa, dan lebih dari 150 juta orang mengalami depresi. Isu tersebut yang akhirnya melahirkan sebuah subkultur di Jepang bernama Yami Kawaii.

Yami yang berarti "sakit" dan Kawaii yang berarti "imut" adalah sebuah gaya berpakaian (style) yang merepresentasikan sebuah kondisi depresi atau masalah kejiwaan dengan balutan yang imut. Style 
tersebut menggabungkan elemen-elemen visual seperti jarum suntik, perban, pil, plester serta alat yang sering digunakan untuk bunuh diri, seperti senjata dan tali. Elemen tersebut dipadukan ke dalam busana pastel dengan motif hati, dan beberapa tulisan dengan font yang cantik, sebagai bagian dari "kawaii". Berpakaian dengan gaya Yami kawaii adalah cara bagi sebagian orang untuk mengirim pesan kepada orang lain bahwa mereka menderita secara psikologis atau gangguan mental yang ditampilkan melalui gaya berpakaian tersebut (Xu, 2018).
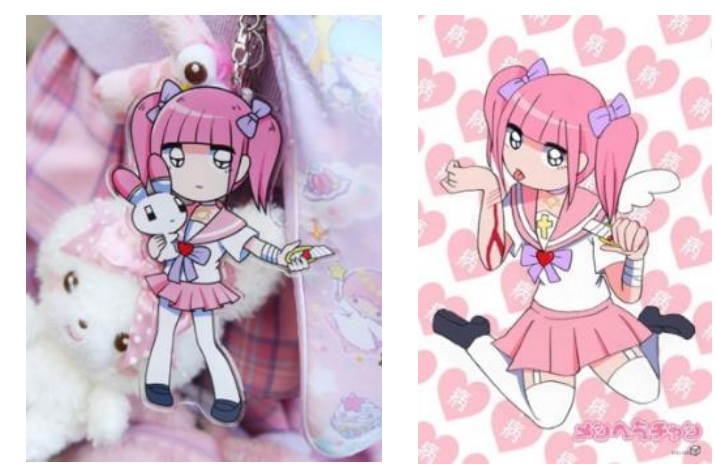

Gambar 1 Karakter Menhera-Chan Sumber:

(https://www.instagram.com/menherachan_officia 1)
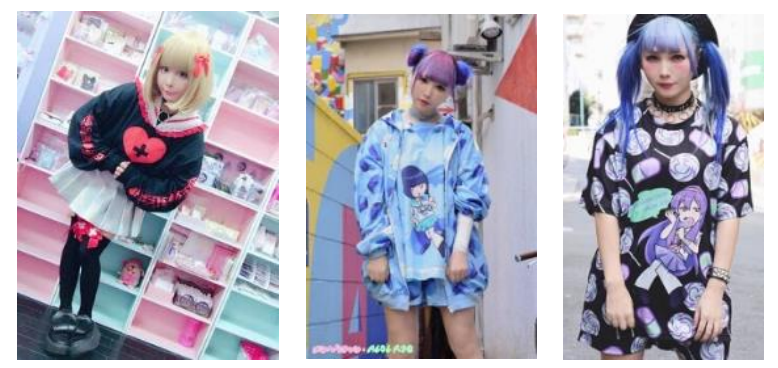

Gambar 2 Gaya Berpakaian Yami Kawaii Sumber:

(https://jfashion.fandom.com/wiki/Yami_Kawaii)

Pakaian dan aksesoris dalam style Yami Kawaii ini tidak hanya sebagai atribut yang digunakan untuk menutup bagian tubuh, tetapi juga mengkomunikasikan makna melalui elemen visual. Hal ini menarik untuk dikaji dalam ranah penelitian dimana tanda tersebut menciptakan pesan dan makna tentang kesehatan mental. Berdasarkan isu dan fenomena yang terjadi perlunya kajian mengenai tanda, dan relasi antar tanda yang dikonstruksi dalam style Yami Kawaii.

Berangkat dari beberapa penelitian terdahulu yang serupa antara lain: (1) $A$ Systematic Review Exploring the Current State of Fashion Criticism (A Focus on the Fashion Designer Exhibition Reviews of Fashion Theory) dari Choi, K. H. (2020) yang membedah fashion sebagai kajian kultural; (2) Penelitian yang ditulis oleh Lai \& Perminiene yaitu Embracing imperfection: Contemporary Fashion Communication and Consumer Well-being berfokus untuk mengidentifikasi ideologi dibalik periklanan fashion kontemporer yang berbicara tentang ketidaksempurnaan dan kaitannya dengan kesejahteraan konsumen; dan (3) Penelitian Siregar (2008) tentang "Kajian Visual Harajuku Style di Indonesia Ditinjau Melalui Pendekatan Unsur-Unsur Fashion Studi Kasus Bandung Dan Jakarta" ini mengkaji aspek visual pada fashion untuk melihat perbedaan kecenderungan style Harajuku. Ketiga penelitian ini menghasilkan output yang sama yaitu fashion bisa menjadi cara komunikasi dilihat dari berbagai aspek seperti budaya, perbandingan style dilihat dari negara, dan kondisi preferensi seseorang.

Selain penelitian terdahulu, peneliti juga melihat dari berbagai teori mengenai fashion dimana menurut Barnard, 1996 fashion dan pakaian merupakan praktik penandaan, didalamnya terjadi pembangkitan makna, yang memproduksi 
dan mereproduksi kelompok-kelompok budaya tersebut, melalui fashion dan pakaian kita membentuk diri kita sebagai makhluk sosial dan kultural, dan kita menyandi (decode) lingkungan sosial dan kultural kita. Terdapat beberapa fungsi fashion as communication yang dikemukakan Malcolm Barnard antara lain: (1) Fungsi Perlindungan; (2) Fungsi Komunikasi; (3) Fungsi Ekspresi Individualistik; (4) Fungsi Nilai Sosial atau Status. Keempat fungsi tersebut menyiratkan bahwa Fashion, pakaian, kostum, dan dandanan adalah bentuk komunikasi artifaktual (artifactual communication) yang bisa menyampaikan pesan-pesan nonverbal (Subandy, 2006).

Fashion biasanya direfleksikan melalui pakaian dan aksesoris. Pakaian/Clothing Types dalam Bunka, (1984) diuraikan berdasarkan jenisnya, pakaian dapat dikelompokkan atas: blouse, shirt, dresses, jacket, suits, vests, coats, skirt, pants, jumpsuit, pullovers. Sedangkan aksesoris merupakan bagian dari pakaian yang berfungsi menambah keindahan pada pakaian. Jika trimming langsung dilekatkan pada pakaian tetapi aksesoris berdiri sendiri akan tetapi masih menjadi satu kesatuan dengan pakaian. Menurut Bunka (1991), aksesoris terdiri atas: topi, dasi, scarf, tali pinggang, tas, sarung tangan, kaos kaki, sepatu, cincin, gelang, anting, dan kalung.

Refleksi fashion berpengaruh dalam pemaknaan yang diungkapkan oleh Malcolm Barnard dimana terdapat dua pemaknaan dalam fashion, antara lain: (1) Pemaknaan Eksternal dimana pihak eksternal seperti kritikus fashion, jurnalis dan orang tua berperan dalam melakukan proses pemaknaan dari proses perancangan; dan
(2) Pemaknaan Internal berupa bentuk, garis dan tekstur. Pemaknaan ini mengandaikan bahwa ada sifat-sifat yang terkandung dalam garmen dan fashion, dan orang hanya melihat untuk bisa memahami maknanya.

Selain kedua pemaknaan tersebut, peneliti mencoba menggunakan konsep semiotika sebagai salah satu metode yang dapat membedah makna terdalam pada fashion. Dalam ilmu semiotika, tanda menjadi konsep utama dalam analisis di mana tanda membantu manusia untuk memaknai pesan yang dimaksud. Dalam tanda terdapat makna yang diinterpretasikan oleh manusia. Secara sederhana tanda dapat berbentuk visual atau fisik yang ditangkap oleh indera manusia yang dapat merepresentasikan sesuatu yang selain dirinya (Danesi, 2010: 7). Bagi Barthes, fashion tersusun dari tiga tingkatan makna yaitu makna denotasi, makna konotasi, dan makna mitos.

Makna denotasi dapat diartikan sebagai tatanan pertama penandaan makna atau "makna jelas". Makna denotasi bersifat faktual, menunjukan bahan pembuat, waktu pembuat, tempat pembuat, dan sebagainya. Contohnya "jas wol" memiliki makna denotasi sebuah pakaian dengan bahan yang keras dan berat, yang dikenakan sebagai pakaian luar, yang pertama kali dibuat di Skotlandia.

Tingkatan kedua adalah makna konotasi yaitu suatu kata atau citra yang membuat orang berpikir atau merasa, atau sebagai asosiasi bahwa sebuah kata atau citra adalah untuk seseorang. Contohnya, makna konotasi dari "jas wol" adalah pakaian gaya lama atau kelas atas. 
Tingkatan ketiga adalah makna mitos yaitu pembenaran bagi nilai-nilai dominan yang berlaku pada periode tertentu (Sobur, 2009), Mitos yang dijelaskan Barthes bukanlah mitos dalam artian yang berkembang di masyarakat yang memiliki arti tahayul atau tidak masuk akal. Namun mitos Barthes adalah sebuah bahasa, mitos adalah sebuah pesan.

Melihat teori yang digunakan dalam penelitian ini, pendekatan metodenya yaitu analisis teks. Analisis ini dipilih karena fashion merupakan sebuah teks, yang dalam tradisi semiotik merujuk pada tanda. Analisis teks berfungsi untuk mengkaji sebuah produk penggunaan bahasa berupa kumpulan atau kombinasi tanda-tanda. Teks didefinisikan sebagai pesan-pesan, baik yang menggunakan tanda verbal maupun visual. Style Yami Kawaii beserta maknanya dalam penelitian ini dipandang sebagai teks yang di dalamnya terdapat kombinasi tandatanda visual.

Teks dalam penelitian yaitu berupa data visual berupa foto dari 5 looks from head-to-toe style Yami Kawaii yang diambil dari internet dan forum-forum yang berhubungan dengan style Harajuku di Jepang menggunakan teknik purposive sampling, penelitian juga melakukan studi literatur mengenai teori tentang fashion communication, struktur dan sistem tanda dan teori element of fashion, dan kajian semiotika dimana bisa mempertajam, memperjelas dan memperkuat pembahasan yang akan diuraikan.

\section{PEMBAHASAN}

Setelah mengumpulkan data visual dengan teknik purposive sampling, maka terpilih 5 obyek kajian berupa foto dari 5 looks from head-to-toe style Yami Kawaii yang diambil dari internet dan forum-forum yang berhubungan dengan style Harajuku di Jepang. Berikut merupakan kelima obyek Style Yami Kawaii:

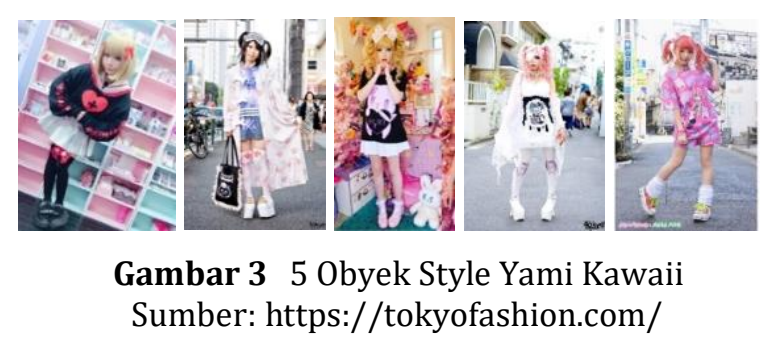

Lima (5) style Yami Kawaii diatas memiliki tanda-tanda visual yang menciptakan sebuah makna. Tanda visual yang dikaji dalam penelitian hanya berfokus pada busana (apparel) dan aksesoris fashion. Berikut merupakan analisa lebih lanjut tentang makna denotasi, konotasi, dan mitos dari tanda visual yang dikonstruksi oleh style Yami Kawaii:

\section{Makna Denotasi Style Yami Kawaii}

Makna denotasi akan dijelaskan melalui dua aspek yaitu busana (apparel) dan Aksesoris Fashion.

\section{a. Busana (Apparel)}

Busana yang dianalisis dalam penelitian ini meliputi: (1) Sweater, Motif Hati, dan Motif Tambah (+); (2) Oversized T-shirt; (3) Tennis skirt dan pleats; (4) Oversized T-shirt, Motif Kelinci, Plester, Perban; (5) Babydoll Lingerie, Lace, Motif Badut; (6) Short. 


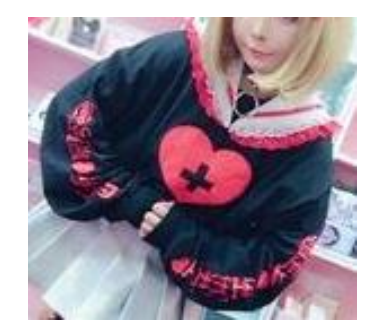

Gambar 4 Sweater Obyek Style 1

- Sweater, Motif Hati, dan Motif Tambah $(+)$. Sweater dapat didenotasikan sebagai atasan (tops) dengan garis leher crewneck, lengan yang lurus (straight), dan manset berjenis ribbed. Berbahan dasar cotton fleece berwarna hitam. Memiliki motif hati berwarna merah dengan tanda tambah (+) di bagian tengahnya, serta tulisan di kedua bagian lengan yang berwarna merah, yang diaplikasikan menggunakan teknik screen printing (lihat Obyek 1). Sweater dengan motif tersebut memiliki konotasi rasa sakit mendalam yang dialami oleh penderita kesehatan mental merupakan keadaan yang berbahaya dan darurat, dibutuhkan kehangatan dan perlindungan bagi orang yang mengalaminya. Motif hati dalam obyek 1 pada style Yami Kawaii mencoba mengkomunikasikan emosi rasa sakit yang mendalam yang dihadirkan melalui bentuk hati. Para filsuf Yunani setuju, bahwa lambang hati terkait dengan emosi terkuat kita, salah satunya adalah emosi kemarahan, amarah, dan rasa sakit (Yalom, 2019). Sedangkan motif tambah (+) identik dengan lambang Palang Merah Internasional. Lambang palang merah diakui dan dihormati secara universal di seluruh dunia sebagai simbol perlindungan, netralitas, dan bantuan kemanusiaan, lambang ini juga diartikan sebagai keadaan darurat dan berbahaya (Krishna, 2017).

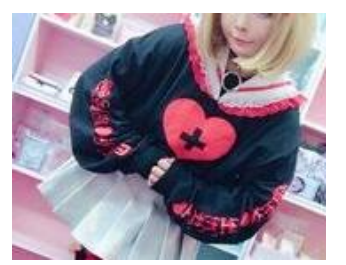

Gambar 5 Oversized T-Shirt Obyek Style 1

- Oversized T-shirt dapat didenotasikan sebagai atasan (tops) yang berbahan dasar cotton, dengan garis kerah berjenis crewneck. Oversized T-shirt memiliki makna konotasi penyampaian pesan tanpa batas tentang isu kesehatan mental yang dapat merangkul semua kalangan masyarakat. Dilihat dari sejarahnya, $t$-shirt memiliki satu model dengan satu warna yaitu putih. Sekitar tahun 1950an Edie Roth menggunakan $t$ shirt sebagai kanvas nya, dia memodifikasi $t$-shirt nya sedemikan rupa dengan cat, air brush, dan media lainnya. Sejak saat itu $t$-shirt menjadi items fashion yang banyak digunakan oleh anak-anak muda untuk mengekspresikan pesan yang ingin mereka sampaikan dan menunjukan identitas mereka sebagai bagian dari satu komunitas tertentu, melalui gambar dan tulisan yang ada pada $t$-shirt yang mereka kenakan. Mereka merasa $t$-shirt menjadi media yang bebas dan tanpa batas untuk menyampaikan pesan yang ingin mereka suarakan (Holoubek, 2015). 


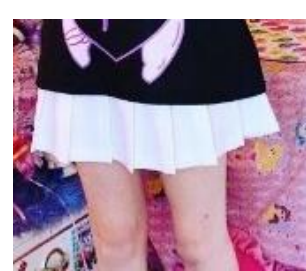

Gambar 6 Tennis Skirt Obyek Style 3

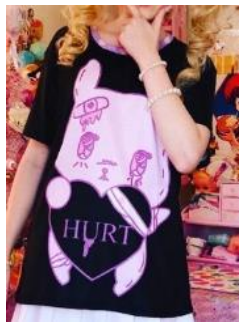

Gambar 7 Oversized Shirt Obyek Style 3
- Tennis Skirt pada obyek 3 dapat didenotasikan sebagai bawahan berwarna putih, berbahan dasar polyster, serta aplikasi knife pleats pada bagian bawah rok. Tennis skirt dengan aplikasi pleats memberikan makna konotasi tentang ungkapan emosi batin. Penderita kesehatan mental seringkali menyembunyikan emosi batin di dalam diri mereka sendiri, mereka merasa tidak nyaman untuk mengungkapkan perasaan mereka yang sesungguhnya. Menurut Deleuze, lipatan merupakan sesuatu yang melampaui sekadar bentuk, struktur, atau dekorasi tapi maknanya berhubungan dengan jiwa dan tubuh. Sebuah kain memiliki permukaan yang datar pada awalnya, setelah diberikan lipatan kain tersebut memiliki teksur. Jika lembaran kain yang datar dianalogikan sebagai jiwa/batin, maka lipatan-lipatan itu merupakan sebuah cara untuk mengubah hal-hal yang ada di dalam jiwa/batin, untuk mampak di permukaan. Maka aplikasi pleats yang ada pada tennis skirt mencoba mengkomunikasikan kepada orangorang yang menderita kesehatan mental untuk berani mengungkapkan perasaan dan emosi batin mereka ke permukaan, dengan cara membicarakannya kepada orang lain, atau meluapkannya dalam bentuk lain seperti tulisan atau gambar.
- Oversized t-shirt pada obyek 3 dapat didenotasikan sebagai atasan (tops) berwarna hitam dengan details kerah crewneck. Terdapat motif bentuk hewan mirip kelinci berwarna pink, dengan gambar plester di bagian kiri yang memperlihatkan ada darah yang mengalir dari plesternya. Pada bagian tangan kanan dan kaki kiri nya terdapat lilitan perban. Kelinci tersebut memegang objek berbentuk hati dengan tulisan "hurt" di bagian tengah nya dengan lilitan perban di bagian kanan. Seluruh elemen yang terkandung dalam oversized $t$-shirt obyek 3 memiliki makna konotasi yaitu isu kesehatan mental ini diharapkan dapat tersampaikan ke semua kalangan masyarakat dan masyarakat lebih cerdas untuk mengidentifikasi luka emosional penderitanya yang seringkali ditutupi. Motif kelinci yang terdapat pada bagian depan $t$-shirt memiliki makna konotasi kecerdasan. Kelinci pada budaya Jepang memiliki simbolisme khusus terkait dengan kecerdasan. Legenda ini berasal dari mitos kelinci putih inaba (Hall, 2018). Sedangkan motif plester dan perban dimaknai sebagai rasa sakit dan luka mendalam yang dialami oleh penderita kesehatan mental. Plester atau yang biasa disebut sebagai band-aid merupakan sebuah simbol untuk 
mengekspresikan perasaan yang tidak dapat mereka bicarakan dalam banyak kasus. Band Aid dan perban sebagian besar ada hubungannya dengan semacam luka, bisa berupa luka fisik atau luka emosional, tetapi band-aid dan perban mewakili luka yang ada atau luka yang sedang disembuhkan (Bisset, 2018).

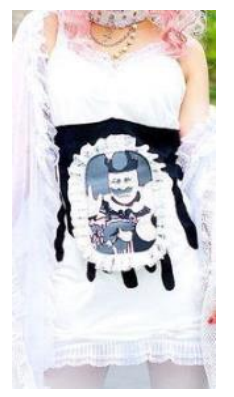

Gambar 8 Babydoll lingerie Obyek Style 4

- Babydoll lingerie pada obyek 4 dapat didenotasikan sebagai item fashion berupa dress, berwarna putih, berbahan katun dan renda, dengan details garis leher spaghetti strap. Pada bagian tengah busana terdapat motif karakter badut berkumis, serta bentuk cairan yang meleleh berwarna hitam, terdapat pula details ruffle dengan bahan renda di bagian tengah busana. Babydoll Lingerie memiliki makna konotasi kepercayaan diri, hal ini didukung dengan sejarah lingerie (pakaian dalam) selama berabad-abad memainkan peran penting, tidak hanya menutupi bagian pribadi tetapi juga membantu wanita menciptakan kepribadian mereka dan memberi mereka kepercayaan diri. Menurut filosofi Prancis, mengenakan "rahasia kecil yang cantik" membantu memancarkan kepercayaan diri dan daya tarik seks (Vernose, 2020). Sedangkan lace (renda) dan motif badut keduanya memiliki makna konotasi kompleksitas. Renda selalu memiliki daya tarik romantis dan feminin. Menurut Sharon Haver, pakar mode dan gaya "Tidak ada bahan lain yang dapat menyarankan begitu banyak asumsi visual yang berbeda". Tergantung pada penerima dan pengaturannya, renda bisa tampak seperti malaikat dan polos pada wanita sekaligus daya tarik seksual. Renda mampu menutupi seluruh tubuh, sekaligus menampakkan segalanya. Keadaan perantara antara pakaian dan ketelanjangan ini, menurut Mario Perniola, lebih erotis daripada ketelanjangan. Dengan menyembunyikan dan memamerkan di bagian yang sama, renda hampir seperti gelas yang setengah penuh atau setengah kosong. Terserah pengguna untuk memilih interpretasinya (Mario, 1989).

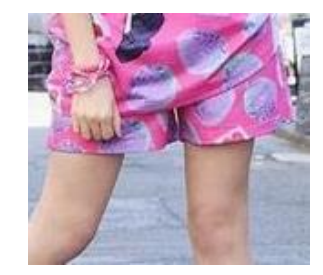

Gambar 9 Short Obyek Style 5

- Short pada obyek 5 dapat didenotasikan sebagai bawahan (bottoms) berupa celana pendek, berwarna pink, berbahan dasar katun, dan memiliki motif susu kotak strawberry berwarna putih, dan strawberry berwarna ungu pada keseluruhan celana, motif tersebut diaplikasikan menggunakan teknik digital print. Short memiliki makna konotasi kesetaraan. Didukung oleh gerakan hak-hak perempuan, seperti 
Gerakan "Pants Are Power" yang memperingati evolusi celana tidak hanya dalam mode, tetapi sebagai simbol kesetaraan bagi wanita (Mondalek, 2021). Dalam style Yami Kawaii, celana bermaksud menyuarakan tentang kesetaraan antara kesehatan mental dan kesehatan fisik yang timpang di masyarakat.

\section{b. Aksesoris Fashion}

Aksesoris fashion yang dianalisis dalam penelitian ini meliputi: (1) Pita Rambut (Ribbon Hairclip); (2) Choker; (3) Eyemask; (4) Platform Shoes.

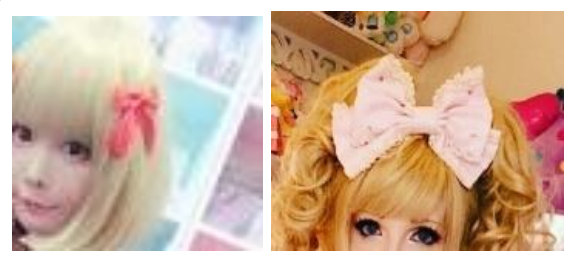

Gambar 10Pita Rambut Obyek Style 1 dan 3

- Pita Rambut (Ribbon Hairclip) Dalam style Yami Kawaii, makna tingkat pertama pita rambut didenotasikan sebagai aksesoris fashion berwarna merah, berbahan dasar kain polyster. Pita rambut memiliki makna konotasi rasa kasih sayang dan cinta. Makna pita rambut sebagai ungkapan kasih sayang dan cinta sesuai dengan tren di Amerika Serikat tahun 1944, yaitu "Girl's Hair-Do Reveals Love Life". Dalam tren ini, gadis-gadis yang mengenakan pita rambut dalam berbagai posisi, untuk mengungkapkan rasa cinta mereka. Menurut Esther Berry seorang pakar studi gender mengungkapkan topik yang berkaitan dengan seksualitas dan cinta pada masa itu dianggap tidak aman untuk percakapan seharihari, dan pita rambut berfungsi sebagai cara untuk mengomunikasikan cinta (Kambhampaty, 2019).

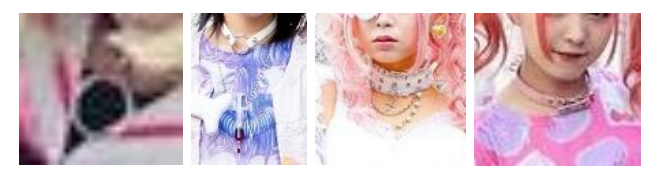

Gambar 11Choker Obyek Style 1, 2, 4, 5

- Choker dapat didenotasikan sebagai aksesoris fashion berupa kalung dengan bahan dasar kulit (leather) yang melingkar pada leher. Choker memiliki makna konotasi perlindungan atas keadaan rentan. Choker sebagai makna perlindungan atas keadaan rentan ini sejalan dengan pemakaian choker oleh Princess of Wales, Alexandra. Dikatakan bahwa dia menggunakan choker sebagai cara untuk menutupi bekas lukanya, yang dia dapatkan setelah operasi masa kanak-kanak. Sejak saat itu choker, menjadi tren dan dimaknai sebagai salah satu item fashion yang memiliki kekuatan khusus untuk perlindungan (Komar, 2017).

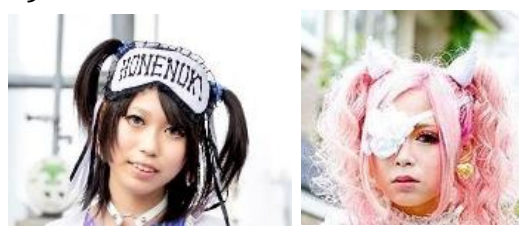

Gambar 12Eyemask Obyek Style 2, 4

- Eyemask didenotasikan sebagai aksesoris fashion berupa penutup mata dengan aplikasi ruffle pada bagian pinggirannya. Eyemask memiliki makna konotasi kesadaran yang rendah terhadap isu kesehatan 
mental. Penutup mata telah menjadi simbol kuat dalam ramalan dan mitologi sejak abad ke-15. Jika dilihat sejarah hukum, penutup mata terlihat dikenakan oleh Lady Justice. Hal ini mewakili tema penolakan terhadap kejelasan, penyangkalan, atau pandangan yang terbatas. Pemakaian penutup mata melambangkan keadaan kesadaran yang rendah, sedangkan melepas penutup mata melambangkan suatu bentuk kebangkitan atau kelahiran kembali (Gazette, 2020).

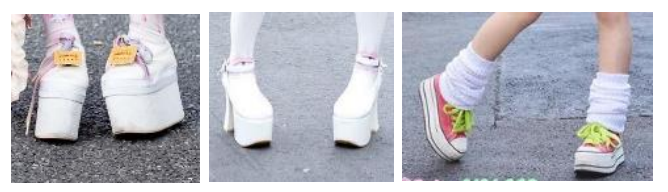

Gambar 13Platform Shoes Obyek Style 2, 4, 5

- Platform Shoes pada style Yami Kawaii didenotasikan sebagai aksesoris fashion berupa sepatu dengan sol tinggi berwarna putih, dengan tali sepatu berwarna ungu muda, dan aksesoris berbentuk persegi berwarna kuning (Obyek 2). Platform Shoes memiliki makna konotasi kesehatan mental merupakan isu yang penting dan perlu perhatian lebih dari masyarakat. Hal ini sejalan dengan sejarah platform shoes yang uncul di Yunani kuno. Sepatu platform dipakai untuk menambah tinggi badan tokoh penting dalam teater Yunani. Para aktor akan mengenakan sandal kulit dengan platform gabus bernama Cothurnus. Semakin penting karakternya, semakin tinggi hak platform Cothurnus. (Wang dan Sylvester, 2015). Dalam konteks kesehatan mental, style Yami Kawaii mencoba untuk mengkomunikasikan bahwa isu kesehatan mental merupakaan isu yang penting dan perlu perhatian yang disimbolkan oleh sepatu platform.

\section{Makna Konotasi Style Yami Kawaii}

Sesuai pemaparan analisa makna denotasi Style Yami Kawaii, menjadi sebuah representasi dari isu kesehatan mental di Jepang yang kurang diperhatikan oleh masyarakat. Melalui tanda visual yang terkandung di dalam style Yami Kawaii menghasilkan tiga makna besar yaitu, (1) Menunjukan emosi dan perasaan para penderita gangguan jiwa, (2) Kritik terhadap masyarakat tentang isu kesehatan mental, dan (3) Harapan ke depan atas isu kesehatan mental.

- Makna konotasi tentang emosi dan perasaan para penderita gangguan jiwa divisualisasikan melalui penanda seperti: motif hati, lambang tambah (+), motif darah, motif luka sayatan, motif plester, motif badut, motif, penggunaan warna hitam, over the knee sock, bahan lace dan tennis skirt dengan aplikasi pleats. Keseluruhan penanda yang digunakan merupakan bentuk-bentuk yang familiar di kehidupan sehari-hari sebagai simbol-simbol yang menandakan penyakit fisik. Hal ini bertujuan agar masyarakat lebih mudah menerima pesan utama yang ingin disampaikan dari style Yami Kawaii yaitu keadaan "sakit", karena kesehatan metal merupakan penyakit yang abstrak dan tidak memiliki wujud yang bisa dilihat 
oleh panca indera, karena melibatkan emosi batin.

- Selain menunjukan emosi batin melalui tanda-tanda visual, makna konotasi yang dikontruksi oleh style Yami Kawaii adalah kritik terhadap masyarakat tentang isu kesehatan mental yang selama ini kurang mendapatkan perhatian, tidak dianggap lebih penting dari kesehatan fisik, hingga dianggap taboo untuk dibicarakan sehari-hari. Kritik tersebut divisualisasikan melalui penanda seperti: eyepatch, choker, platform shoes, dan short.

- Makna konotasi yang terakhir merupakan sebuah harapan untuk para penderita gangguan jiwa maupun isu kesehatan mental itu sendiri. Edukasi tentang isu kesehatan mental diharapkan dapat tersampaikan ke seluruh kalangan masyarakat untuk diberikan perhatian lebih dan tersedianya lembaga perlindungan yang layak. Bagi penderita gangguan jiwa nya sendiri, harapan yang ingin disampaikan melalui style Yami Kawaii adalah kesembuhan, rasa bahagia, dan kasih sayang dari orang-orang sekitar. Keseluruhan makna konotasi tersebut divisualisasikan melalui penanda, antara lain: oversized $t$-shirt, sweater, motif kelinci, babydoll lingerie dan robe, ribbon, dan penggunaan warna-warna pastel seperti pink dan ungu.

\section{Makna Mitos Style Yami Kawaii}

Style Yami Kawaii juga memiliki makna mitos di dalamnya berupa cerita, narasi dan konotasi-konotasi tersebut ditampilkan melalui objek-objek seperti pakaian dan aksesoris, siluet, garis, details, motif, bahan, dan warna.

- Yami kawaii adalah sebuah gaya berpakaian yang merepresentasikan sebuah kondisi depresi atau masalah kejiwaan dengan balutan yang imut. Dalam style Yami Kawaii, elemen-elemen yang menandakan "imut" sangat mendominasi, dari mulai gaya rambut, make-up, gaya berpakaian dengan warna-warna pastel yang lembut, hingga penggunaan atribut seperti pita berbahan dasar lace. Berdasarkan elemen-elemen yang ditampilkan dalam objek tersebut dapat disimpulkan bahwa kesehatan mental dapat dibalut dengan tampilan yang imut merupakan mitos dari style Yami Kawaii.

- Menurut Barthes mitos dapat terbentuk dari sebuah makna yang dapat diakses indra penglihatan, dan sebagai tanda yang total (total linguistic sign) ia memiliki sejarah panjang yang direduksi dalam sebuah mitos. Sebagai sebuah makna, mitos kesehatan mental ditampilkan dengan balutan yang imut dapat dilihat oleh pengindraan, berupa elemen visual yang terkandung dalam style tersebut seperti: warna-warna pastel (pink dan ungu), penggunaan pita rambut, penggunaan material lace, dll.

- Sementara sebagai tanda yang total, gaya berpakaian yang imut (kawaii) di Jepang khususnya di Harajuku memiliki sejarah panjang. Gaya Harajuku memiliki subsub yang beragam sebagai wujud kreativitas anak-anak muda di Jepang, namun konsep kawaii sebagai budaya yang mendominasi pada budaya populer di Jepang, seperti style Decora, sweet Lolita, Yume Kawaii, hingga pada 
akhirnya muncul Yami Kawaii. Sejarah panjang gaya berpakaian dengan konsep yang imut tersebut diapropriasi sebagai tanda secara reduktif, konsep kawaii tersebut dipinjam untuk dijadikan mitos pada style Yami Kawaii.

- Mitos merupakan sesuatu yang dihasratkan oleh konsumen, namun sulit untuk dipraktikkan dalam kehidupan sehari-hari. Contohnya, isu kesehatan mental di dalam masyarakat Jepang merupakan hal yang tabu. Orang Jepang cenderung diam dan menyembunyikan masalah yang mereka hadapi. Mengungkapkan kesedihan, rasa sakit, dan penderitaan yang mereka hadapi merupakan sesuatu yang sulit dipraktikkan dalam keseharian, karena sering dianggap sebagai orang yang lemah. Sehingga, emosi batin yang mereka rasakan dituangkan ke dalam bentuk busana dan tanda-tanda visual yang ada pada style Yami Kawaii. Tandatanda tersebut dikonsumsi untuk menarik rasa simpati kepada orangorang disekitarnya.

\section{SIMPULAN}

Yami-Kawaii adalah sebuah subkultur di Jepang yang mulai muncul dan dikenal oleh masyarakat sejak tahun 2018. Yami Kawaii adalah sebuah gaya berpakaian yang merepresentasikan sebuah kondisi depresi atau masalah kejiwaan dengan balutan yang imut. Style Yami Kawaii ini tidak sematamata muncul begitu saja, style ini muncul dari sebuah respon terhadap isu tentang kesehatan mental dan bunuh diri di Jepang.

Makna denotasi meliputi aspek busana (apparel) yang meliputi: (1) Sweater, Motif Hati, dan Motif Tambah (+); (2) Oversized T- shirt; (3) Tennis skirt dan pleats; (4) Oversized T-shirt, Motif Kelinci, Plester, Perban; (5) Babydoll Lingerie, Lace, Motif Badut; (6) Short. Sedangkan Aksesoris Fashion meliputi: (1) Pita Rambut (Ribbon Hairclip); (2) Choker; (3) Eyemask; (4) Platform Shoes.

Tanda visual dalam style Yami Kawaii saling berelasi untuk menciptakan makna konotasi tentang isu kesehatan mental di Jepang yang kurang diperhatikan oleh masyarakat. Tiga makna besar yaitu yang ditampilakan dalam style Yami Kawaii antara lain: (1) Menunjukan emosi dan perasaan para penderita gangguan jiwa, (2) Kritik terhadap masyarakat tentang isu kesehatan mental, (3) Harapan ke depan atas isu kesehatan mental.

Makna konotasi dari style Yami Kawaii tersebut jika disampaikan secara berulang kepada masyarakat dapat membentuk sebuah mitos. Mitos dalam pengertian Barthes adalah sebuah cerita atau narasi yang dibangun yang disampaikan secara berulang-ulang sehingga menjadi sesuatu yang dipercaya kebenarannya. Yami Kawaii adalah sebuah gaya berpakaian yang merepresentasikan sebuah kondisi depresi atau masalah kejiwaan dengan balutan yang imut. Dalam style Yami Kawaii, elemenelemen yang menandakan "imut" sangat mendominasi, dari mulai gaya rambut, make-up, gaya berpakaian dengan warnawarna pastel yang lembut, hingga penggunaan atribut seperti pita berbahan dasar lace. Berdasarkan elemen-elemen yang ditampilkan dalam objek tersebut dapat disimpulkan bahwa kesehatan mental dapat dibalut dengan tampilan yang imut merupakan mitos dari style Yami Kawaii. 
Style Yami Kawaii ini tidak semata-mata muncul begitu saja, style ini muncul dari sebuah respon terhadap realita kehidupan sosial di Jepang tentang isu tentang kesehatan mental dan bunuh diri. Dalam budaya Jepang terdapat istilah hikikomori, yaitu sebuah keadaan dimana seseorang menyendiri dan membatasi dirinya dari lingkungan luar. Selain itu, pada literatur Jepang selama ini kerap mengglorifikasi perilaku menyendiri sebagai hal yang mulia. Kecenderungan hidup sendiri mengingatkan pada kodokushi, yaitu fenomena meninggal dalam kesendirian. Kebudayaan Jepang tersbut menjadi sebuah pemicu semakin maraknya isu bunuh diri di Jepang.

Dari banyaknya kasus bunuh diri yang terjadi, Jepang dan telah melakukan banyak cara untuk menanggulanginya, misalnya anak-anak muda di Jepang juga memiliki caranya sendiri untuk menanggulangi masalah-masalah sosial yang terjadi di masyarakat dengan membuat sebuah trend budaya popular yang bersifat fleksibel, informal dan lebih mudah diakses oleh anakanak muda, yaitu subkultur Harajuku. Subkultur Harajuku tersebutlah yang menjadi akar dan budaya yang diadopsi oleh style fashion Yami Kawaii. Sama halnya dengan style Harajuku lainnya, Yami Kawaii adalah respon dan bentuk kekecewaan masyarakat atas isu kesehatan mental di Jepang. Dapat disimpulkan bahwa subkultur Harajuku dalam budaya Jepang dipandang sebagai sebuah wadah bagi anak-anak muda untuk secara bebas mengkomunikasikan keresahan apapun yang mereka rasakan terhadap realita kehidupan sosialnya.

\section{DAFTAR PUSTAKA}

[1] Berek, D. I. (2014). Fashion Sebagai Komunikasi Identitas Sub Budaya (Kajian Fenomenologis terhadap Komunitas Street Punk Semarang). JURNAL INTERAKSI, Vol III No.1, 56

[2] Barnard, Malcolm, Fashion As Communication, diterjemahkan/editor: Idi Subandy Ibrahim, Fashion Sebagai Komunikasi, Jalasutra, Jogjakarta, 2006.

[3] Barthes, R. (1977). IMAGE MUSIC TEXT, Diterjemahkan oleh Stephen Heath. London: Fortana Press.

[4] Barthes, R. (1993). Mythologies, Diterjemahkan oleh A. Lavers. New York: THE NOONDAY PRESS.

[5] Fiske, J. (1990). Cultural and Communication Studies. Yogyakarta: Jalan Sutra.

[6] Frings, Ginny Stephens, 2007, Fashion: From Concept to Costumer, edisi 9, US:Pearson.

[7] Hartley, John. 2004. Communication, Cultural and Media Studies: The Key Concept. Terjemahan oleh: Idy Subandi Ibrahim. 2010. Yogyakarta: Jalasutra

[8] Hendariningrum, R., \& Susilo, M. E. (2008). Fashion Dan Gaya Hidup : Identitas Dan Komunikasi. Jurnal Ilmu Komunikasi, 25-32.

[9] Kenneth L. Smith, S. M. (2004). Handbook of Visual Communication: Theory, Methods, and Media. Taylor \& Francis.

[10]Nugraha, R. P. (n.d.). Fashion Sebagai Pencitraan Diri dan Identitas Budaya. Menggagas Pencitraan Berbasis Kearifan Lokal , 643-652.

[11]Pinandita, J. M. (2009). Punk!: FesyenSubkultur-Identitas. Halilintar Books.

[12]Siregar, B. S. (2008). Kajian Visual Harajuku Style di Indonesia Ditinjau Melalui Pendekatan Unsur-Unsur Fashion Studi Kasus Bandung Dan Jakarta. Bandung: Institut Teknologi Bandung. 
[13]Smith K., Moriarty S., Barbatsis G., \& Kenney K. (2005). Handbook of Visual Communication: Theory, Methods, And Media. America: Lawrence Erlbaum Associates.

[14] Stone, Elaine, 2006, The Dynamic of Fashion, Fairchild, New York.

[15] Takamura, Zeshu, Fashion with Style, Graphic-Sha, Japan

[16] Tokyo Street Fashion Photos. (2018). Retrieved from Tokyo Fashion: http://tokyofashion.com

[17] Trisnawati, T. Y. (2011). Fashion sebagai Bentuk Ekspresi Diri dalam Komunikasi. The Messnger, 36-47 